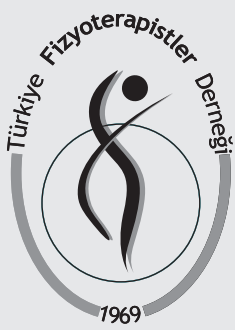

\section{Türk Fizyoterapi} ve Rehabilitasyon Dergisi

$$
201627(2) 34-41
$$

Güzin KARA, PT, MSc ${ }^{1,2}$ Kazakos KYRIAKOS, MD, PhD Panagiotis TSAKLIS, Prof, PT, ATC, B.PhEd, $P h D^{2}$

\title{
COMPARISON BETWEEN A TRUNK TRAINING MACHINE AND CONVENTIONAL EXERCISES FOR TRUNK EXTENSORS AND EFFECT ON STANCE WEIGHT DISTRIBUTION OF YOUNG ADULTS: A PILOT STUDY
}

\section{RESEARCH ARTICLE}

\section{ABSTRACT}

Purpose: The aim of this study was to determine if there was a difference between activities of multifidus and erector spinae muscles, when trained using the same patterns through a trunk training machine (TTM) and conventional exercises for trunk extensors (CETE), and to investigate the postural changes in weight bearing between groups after interventions of TTM and CETE, respectively.

Methods: 20 healthy males with a mean age of $24.5 \pm 3.7$ years participated in the study. First day, muscle EMG activities were recorded while all of the participants performed TTM and CETE exercises. Next day, they were separated into two groups. TTM $(n=10)$ and CETE groups $(n=10)$ were trained for 5 bouts. The body weight distribution was measured before and after the training periods.

Results: There was a significant difference between total TTM-Work output and CETE-Work output $(p<0.01)$. Although no significant differences were found between two legs' weight distribution in both groups before and after the intervention program, standard deviation and frequencies of the values in TTM group for both legs were significantly different, and higher than CETE group $(p=0.00)$.

Discussion: In conclusion, the TTM training appears to demand less muscle activity, thus less energy consuming and produced better stance outcome in the same time when compared with CETE. It is suggested that more participants are needed for a further research to reveal the effect of TTM intervention on the body weight distribution clearly. It is also recommended to plan new research in this field on other populations such as geriatrics or neurological disorders.

Key Words: Exercise; posture; physical training; weight bearing.

\section{GÖVDE ÇALIŞMA ARACI İLE GÖVDE EKSTANSÖRLERI içiN GELENEKSEL EGZERSIZLERIN KARŞILAŞTIRILMASI VE GENÇ ERIŞKKINLERIN DURUŞ FAZINDA AĞIRLIK DAĞILIMI ÜZERINE ETKISI: PILOT ÇALIŞMA}

Geliş Tarihi: 11.09.2015 (Received) Kabul Tarihi: 11.06.2016 (Accepted)

\section{Illetişim (Correspondence):}

Güzin KARA, MSc, PT. Pamukkale University, School of Physical Therapy and Rehabilitation, Kinikli Campus, 20070 Denizli, Turkey E-mail: guzin1196@pau.edu.tr

1 School of Physical Therapy and Rehabilitation, Pamukkale University, Denizli, Turkey

2 Biomechanics \& Ergonomics Lab, Department of Physiotherapy, Alexander Technological Educational Institute of Thessaloniki (ATEITH), Greece

3 Department of Nursing ATEITH, Lab of Metabolism, MSc Course "Diabetes Mellitus Care"

\section{ARAŞTIRMA MAKALESi}

\section{ÖZ}

Amaç: Bu çalışma gövde çalışma aracı (GÇA) ve gövde ekstansörleri için geleneksel egzersizlerin (GEGE) aynı paternde uygulanması sırasında multifidus ve erector spinae kas aktiviteleri arasında bir fark olup olmadığını tespit etmek ve sırasıyla GÇA ve GEGE ile uygulanan programın ardından gruplar arasında ă̆ırlık aktarmada postüral değişiklikleri araştırmak amacıyla planlanmıştır.

Yöntemler: Çalışmaya yaş ortalaması 24.5 3 3.7yıl olan 20 sağlıkı erkek katılmıştır. İlk gün tüm katılımcılar GÇA ve GEGE egzersizlerini yaparken kas EMG aktiviteleri kaydedilmiştir. Ertesi gün katılımcılar iki gruba ayrılmıştır. GÇA $(n=10)$ ve GEGE grubu $(n=10) 5$ kez çalışmışlardır. Vücut ağılık dağıımı eğitim sürecinden önce ve sonra ölçülmüştür.

Sonuçlar: Toplam GÇA ve GEGE çalışma sonuçları arasında istatistiksel olarak anlamlı bir fark bulunmuştur $(p=0,00)$. Her iki grupta da çalışma öncesi ve sonrası iki bacağın ağırlık dağılımları arasında anlamlı bir fark bulunmamasına rağmen, GEGE grubundan daha fazla olduğu göze çarpan, GÇA grubunda her iki bacak için değerlerin standart sapma ve frekanslarında anlamlı bir fark bulunmuştur $(p=0.00)$.

Tartışma: Sonuç olarak, GEGE ile karşılaştırıldığında GÇA çalışmasının daha az kas aktivitesi, dolayısıyla daha az enerji tüketimi gerektirdiği ve aynı sürede daha iyi sonuç durumuna ulaştırdığı görünmektedir. GÇA çalışmasının gövde ağırlık dağıımı üzerine etkisini açıkça ortaya çıkarabilmek için ileriki çalışmalarda daha fazla katılımcıya intiyaç olduğu düşünülmüştür. Ayrıca geriatrik veya nörolojik bozukluğu olanlar gibi diğer popülasyonlarda bu alanda yeni çalışmaların planlanması önerilmektedir.

Anahtar Kelimeler: Egzersiz; postür; fiziksel eğitim; ağırlık aktarma. 


\section{INTRODUCTION}

Researches about posterior muscle chain (PMC) activity have a wide coverage in the literature owing to realization of their importance on the control of trunk in relation to pelvis. PMC activating methods such as postural exercises, core stabilization exercises, interventions through the machines and their effects on the posture and trunk stability have been widely discussed.

As well as there are more collaborative muscles of the PMC, one group of the posterior spine muscle chain are the lumbar extensor muscles (1). Two of the chain muscles are M. Multifidus and M. Erector Spinae. Optimal condition of these muscles includes optimal motor control, strength and endurance (2-4). An especially important function of muscles is their contribution to trunk stability, and it is thought that the co-activation of several trunk muscles is needed to achieve a degree of spinal stability (5-10).

In the literature, there are various kind of exercises to activate PMC (11-13). Conventional exercise of the trunk extensors (CETE) is a way to increase the muscle activity of PMC and generally is performed as over ground exercises on a mat. Appropriate strength training may have a positive effect on maximal strength $(14,15)$, muscle size $(16,17)$, muscle architecture (18) and the control of muscular contraction force (14-20). Another function that is often observed to improve with resistance training is postural stability $(21,22)$. In addition to strength exercises, muscle stretching exercises are also used in conventional physical therapy (23). Stretching can provide a range of health-related motion benefits. It is considered that flexibility training can be an integral component in the prevention of injuries, as well as a method of improving performance in daily activities in a good posture (24).

Core stabilization exercises are other most used exercise types to activate core muscles such as PMC. Many studies have found a significant gain in the holding time of a certain posture when stability exercises were performed chronically as training regimens (25-30). This type of exercises can be used to strength trunk and core stabilizing muscles, decrease standard deviation of center of pressure in standing position, control of motion and balance (30). Core stabilization exercises are maximized when an exercise is performed under dynamic conditions (e.g. by using a therapeutic Swiss ball) rather than under static conditions (e.g. over ground exercises), since proprioception and motor area of cerebrum are stimulated and balance ability is improved under dynamic conditions $(9,11)$.

Freespine $\mathrm{T}^{\mathrm{TM}}(31)$, is a new trunk training machine (TTM) to work out horizontal cross training of the spine, back muscles and joints. The main aim of TTM is to keep vertebral discs elastic and backbone flexible by naturally exercising the Spinal Column in 3 dimensions. TTM is designed for total body and backbone workout with a flexible spine, aligning the core muscles' imbalance, decompressing the vertebral discs, reducing rate of perceived exertion, energy and training time and having a good cardio effect (31).

Although there is a lot of study about CETE and core stabilization exercises, less study about TTMs are present in the literature. Furthermore, there is no study about Freespine ${ }^{\mathrm{TM}}$. Therefore, the aims of this study were:

1. To examine the mentioned advantages of TTM in comparison with CETE,

2. To determine, if there is a difference between the muscle activity of multifidus and erector spinae, while TTM and CETE are implemented under the same patterns,

3. To investigate the postural changes in weight shifting between groups, after an intervention program with the TTM and CETE, respectively.

\section{METHODS}

\section{Subjects}

Twenty healthy male subjects participated in this study in the Biomechanics \& Ergonomics Laboratory at the Department of Physiotherapy of the Alexander Technological Educational Institute of Thessaloniki between May and September 2014.

The subjects were university students and they had low to medium level athletics experience. Their mean \pm SD age, height and weight were $24.5 \pm 3$.7years, $1.75 \pm 4.11 \mathrm{~m}, 69.5 \pm 19.10 \mathrm{~kg}$, respectively. The inclusion criteria were 


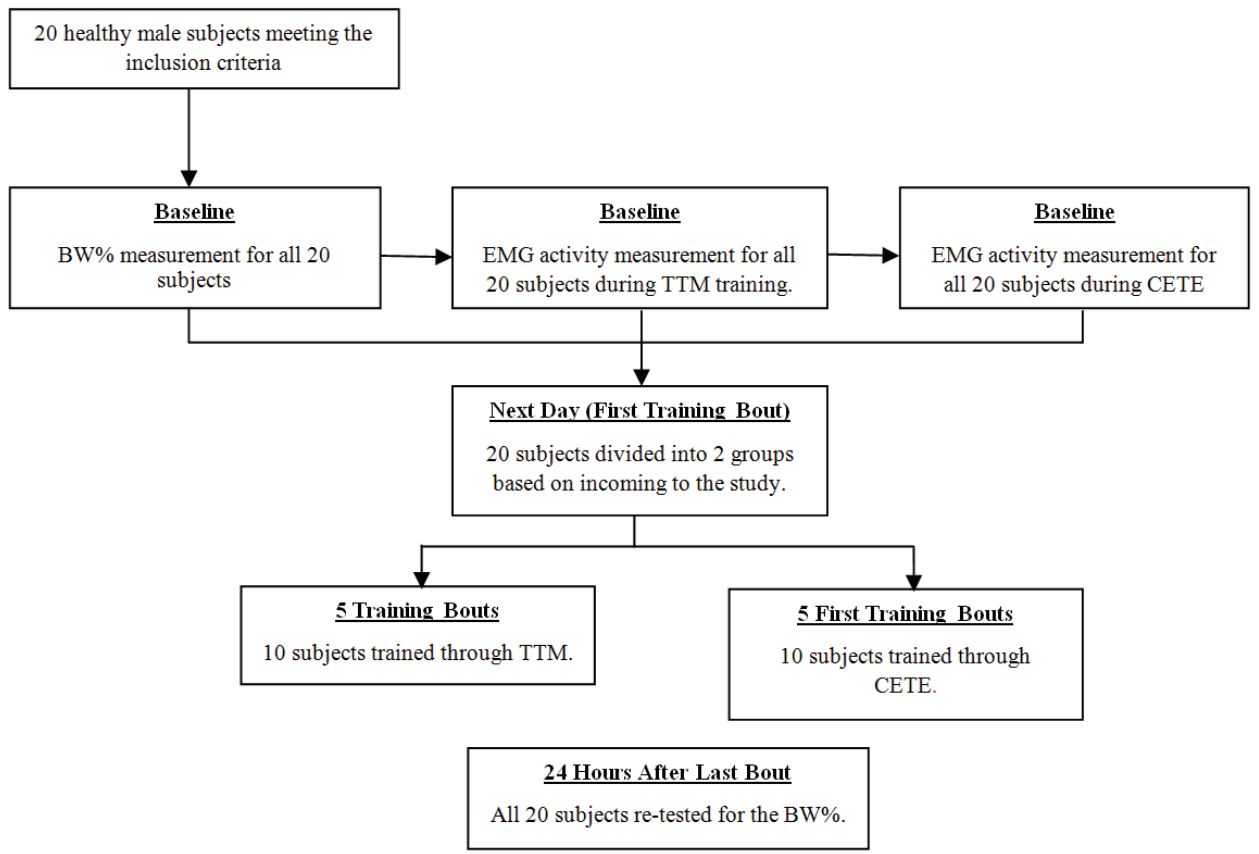

Fig. 1: Flow Diagram of The Subjects

BW\%: Body weight distribution

EMG: Electromyography
TTM: Trunk training machine (Freespine ${ }^{\mathrm{TM}}$ )

CETE: Conventional Exercises of The Trunk Extensors
1) being 21-27 year-old healthy male,

2) doing exercise 3 times a week in a gym, stadium etc. and having low to medium level of athletic experience,

3) the completion of the procedure.

The exclusion criteria were

1) being less than 21 year old and more than 27 year old,

2) not doing exercise or being a systematic athlete,

3) not completing the procedure (Fig. 1).

Each subject was informed about the study and the consent. The study was approved by the ATEITH Committee of Deontology and Ethics (No: 1634/2303-2014).

\section{Research Protocol}

First day, body weight distribution (BW\%) of all subjects was measured (baseline). Then, they practiced TTM and CETE protocols and electromyography (EMG) measurements were done to investigate the selected muscle activities, during these applications.

For the next five training bouts (days), they were separated in two groups of 10 subjects. They joined to each group, based on their order of attendance to the study (i.e. the first subject to group

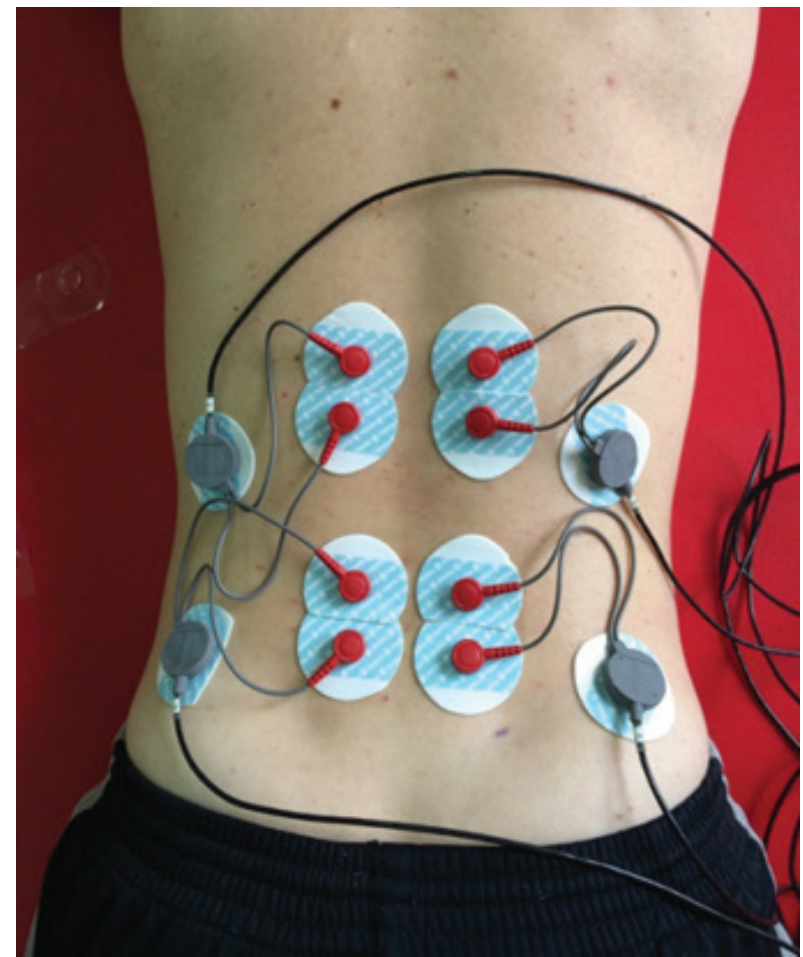

Fig. 2: The Placement of EMG Electrodes

1, the second subject to group 2, etc.) (Fig.1). Both groups performed 5 training bouts, with an interval of 48 hours (total period 13 days). They started the next day of the baseline and re-tested for the BW\%, 24 hours after the last training day. 

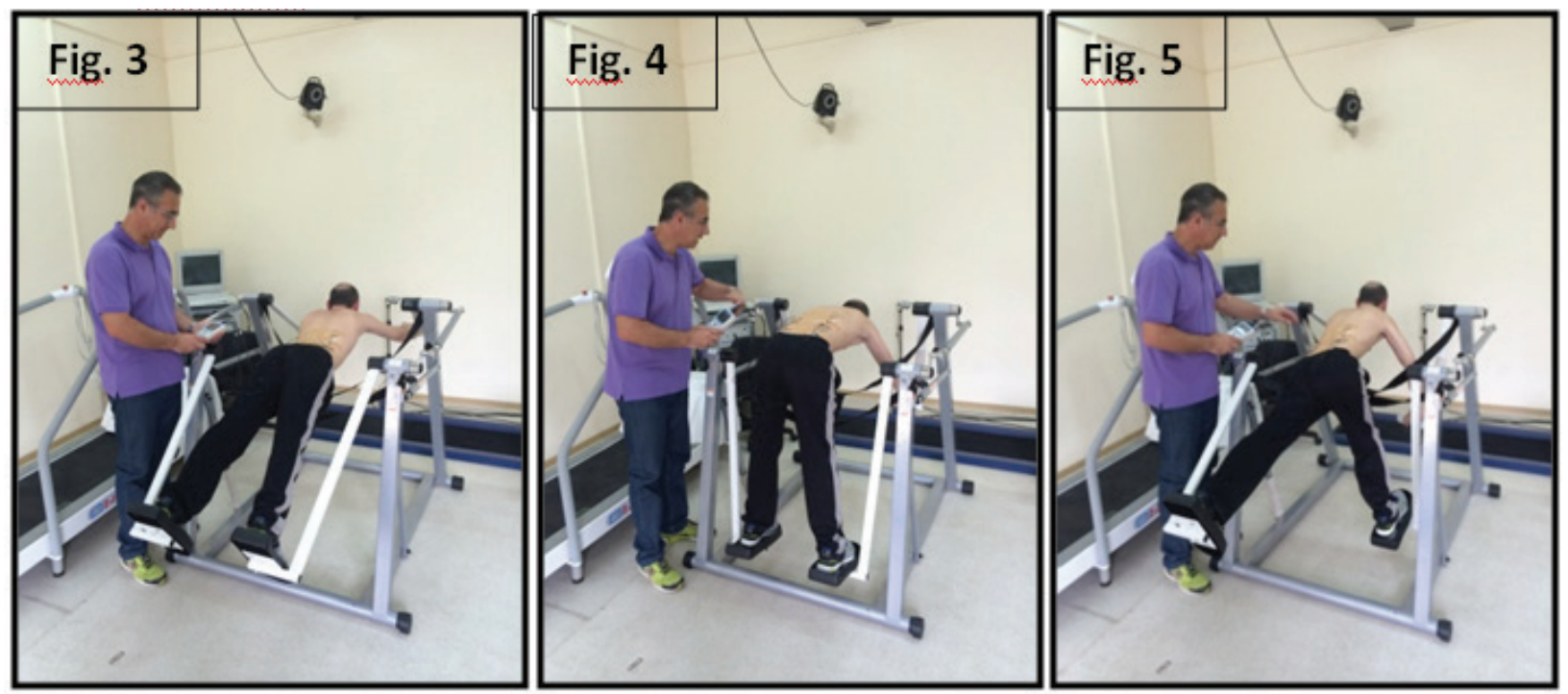

Fig. 3: Bilateral upper and lower extremity extension

Fig. 4: Bilateral upper and lower extremity flexion

Fig. 5: Ipsilateral upper and lower extremity extension

All the assessments and training protocol were applied by a physical therapist under supervision of a senior physical therapist. The subjects were blind to the study.

\section{Body Weight Distribution (BW\%) Measure- ment}

The body weight distribution (BW\%) measurement was performed using two force plates (BERTECCorpFP40X60-07-1000, Columbus OH), with the subjects placing barefoot, adapting a quite bipedal standing position and looking at a fix point in front. They were also asked to try to adjust their stance before the measurement began. The recording was

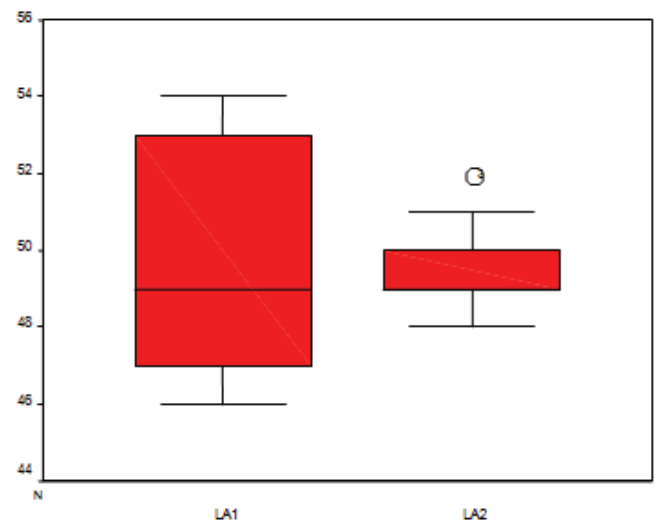

Table 1: TTM Vs CETE EMG total work $(\mu \mathrm{V})$

\begin{tabular}{|l|l|l|l|}
\hline Variables & $\mathbf{n}$ & Mean \pm SD & p \\
\hline TTM-Work & 20 & $16101.40 \pm 1118.11$ & 0.000 \\
\cline { 1 - 2 } CPE-Work & 20 & $73867.30 \pm 7626.10$ & \\
\hline
\end{tabular}

TTM: Trunk Training Machine;

EMG: Electromyography;

CETE: Conventional Exercises of The Trunk Extensors;

Vs: Versus.

lasted 15 seconds in a sample frequency of 1000 $\mathrm{Hz}$. The percentages of body weight per lower extremity were calculated with the Vicon Polygon software (@Vicon Motion Systems Ltd. UK).

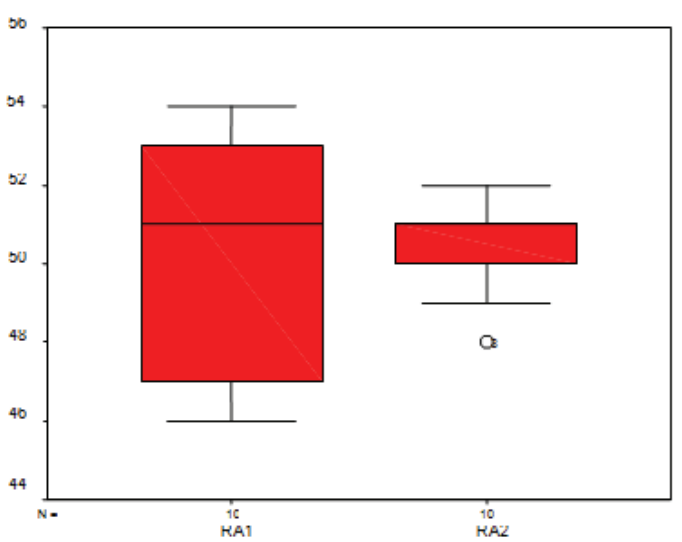

Graphics 1 \& 2: Ranges for left \& right leg distribution between measures, in group $A$ LA1: left leg group A, 1st measurement; LA2: left leg group A, 2nd measurement; RA1: right leg group $A$, 1st measurement; RA2: right leg group $A, 2$ nd measurement. 

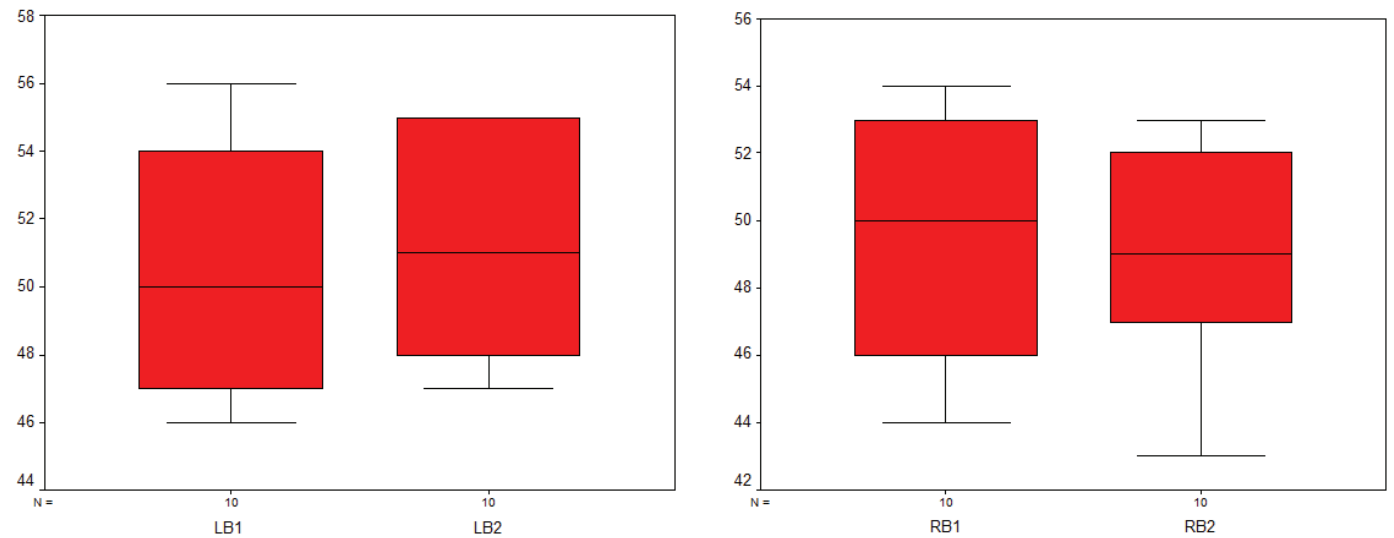

Graphics 3 \& 4: Ranges for left \& right leg distribution between measures, in group $B$ LB1: left leg group B, 1st measurement; LB2: left leg group B, 2nd measurement; RB1: right leg group $B, 1$ st measurement; RB2: right leg group $B, 2$ nd measurement.

\section{Muscle Activity Measurement}

EMG recording was performed with the 8-channel Biomonitor ME6000 (Mega Electronics LTD). Prior to EMG recording, participants' skin was shaved, sandpapered and carefully cleaned with $70 \%$ alcohol. Disposable pre-gelled self-adhesive bipolar surface electrodes $(\mathrm{Ag} / \mathrm{AgCl} ; 0.8 \mathrm{~cm}$ diameter, Blue Sensor N-00-S, Medicotest A/S, Ølstykke, Denmark) were placed on and aligned with a line from caudal tip posterior spina iliaca superior to the interspace between L1 and L2 interspace at the level of $L 5$ spinous process (i.e. about $2-3 \mathrm{~cm}$ from the midline) for Multifidus muscle, with an inter-elect- rode distance of $2 \mathrm{~cm}$ in accordance with SENIAM (Surface ElectroMyoGraphy for the Non-Invasive Assessment of Muscles) guidelines (32). The neutral electrodes were placed on the iliac crest bilaterally. The samewas also done for lliocostal branch of Erector Spina muscle. Placement point was one finger width medial from the line from the posterior spina iliaca superior to the lowest point of the lower rib, at the level of L2. The neutral electrodes were placed on the lower rib bilaterally (Fig. 2).

After placement, the function of the electrodes was tested and stabilized properly with a tape to avoid noise.

Table 2: Descriptive statistics and comparisons of left/right leg weight distribution, during 1 st and 2nd measure, for group A (TTM) and B (CETE)

\begin{tabular}{|c|c|c|c|c|c|c|c|}
\hline Variables & $n$ & Range & Min (\%) & $\operatorname{Max}(\%)$ & Mean \pm SD & $\mathbf{p}$ & $t$ \\
\hline LA1 & 10 & 8 & 46 & 54 & $49.90 \pm 3.07$ & \multirow[t]{2}{*}{0.92} & \multirow[t]{2}{*}{-0.10} \\
\hline RA1 & 10 & 8 & 46 & 54 & $50.10 \pm 3.07$ & & \\
\hline LA2 & 10 & 4 & 48 & 52 & $49.60 \pm 1.17$ & \multirow[t]{2}{*}{0.30} & \multirow[t]{2}{*}{-1.07} \\
\hline RA2 & 10 & 4 & 48 & 52 & $50.40 \pm 1.17$ & & \\
\hline LB1 & 10 & 10 & 46 & 56 & $50.20 \pm 3.79$ & \multirow[t]{2}{*}{0.87} & \multirow[t]{2}{*}{0.16} \\
\hline RB1 & 10 & 10 & 44 & 54 & $49.80 \pm 3.79$ & & \\
\hline LB2 & 10 & 8 & 47 & 55 & $51.20 \pm 3.29$ & \multirow[t]{2}{*}{0.28} & \multirow[t]{2}{*}{1.14} \\
\hline RB2 & 10 & 10 & 43 & 53 & $48.80 \pm 3.43$ & & \\
\hline
\end{tabular}

TTM: Trunk Training Machine; CETE: Conventional Exercises of The Trunk Extensors; LA1: left leg group A, 1st measurement; LA2: left leg group A, 2nd measurement; RA1: right leg group $A$, 1st measurement; RA2: right leg group $A$, 2nd measurement; LB1: left leg group B, 1st measurement; LB2: left leg group B, 2nd measurement; RB1: right leg group $B, 1$ st measurement; $R B 2$ : right leg group $B, 2$ nd measurement 


\section{Exercise Procedure for EMG activity measure- ment}

The subjects had to withstand for two different practices, a) use a TTM and b) use a CETE application, with a rest of 15 minutes between the practices.

They performed two type of exercises during each practice, including bilateral upper and lower extremity extension consecutively (exercise1)and ipsilateral upper and lower extremity extension (exercise2) for TTM and for CETE on mat.

While each exercise was performed using the TTM or the CETE, a metronome was used to fix cadence at $30 \mathrm{bip} /$ minute (every $2 \mathrm{~s}$ ) (31). Every practice, started with exercise 1 . Both exercises lasted 2 minutes with an alternation of $30 \mathrm{~s}$ for each.

\section{Training Protocol}

Each subject in group A performed bilateral upper and lower extremity extensions, consecutively for 90 seconds with 90 seconds rest, on the TTM (Fig. 3\&4), followed by ipsilateral upper and lower extremity extension consecutively for 90 seconds with 90 seconds rest, for a total of 15 minutes (Fig. 5). A metronome was used to fix the cadence at $20 \mathrm{bip} /$ minute (every 3 s) (31).

The subjects in group B performed the same exercises protocol, on a mat on the ground.

\section{Statistical Analysis}

Statistical analyses were performed using the Statistical Package for the Social Sciences (SPSS version 21.0). Normal distribution analysis was applied to decide parametric tests. Wilcoxon Matched Pairs Test was applied to analyze differences between groups for BW\% before and after TTM and CETE for BW\% each training method in itself and Two Independent Samples Test was used to compare the TTM-Work and CETE-Work outputs. Numbers, percentages, minimum and maximum values, me$\mathrm{an} \pm \mathrm{SD}$ were also recorded as descriptive statistics. $P$ values $\leq 0.05$ were considered to indicate statistical significance.

\section{RESULTS}

There was no difference between the groups related to the characteristics of demographics and the assessed parameters before intervention ( $p>0.05)$.

According to the muscle activity measurements, there was a significant difference between total TTM-Work and CETE-Work ( $p=0.00)$ (Table1).

Descriptive statistics of left and right leg BW\% for both groups are shown in Table 2.

There was no significant difference between measures for group $A$ in first $(p=0.92)$ and second $(p=0.30)$ BW\% measurements ( $p>0.05)$ (Table 2).

There was no significant difference between measures for group $B$ in first $(p=0.87)$ and second $(p=0.28)$ BW\% measurements ( $p>0.05)$ (Table 2).

Graphics 1\&2 present ranges for the left and right leg distribution between measures in group $A$ and the means were around 50 for both the first and second measurements (Graphics 1\&2).

Graphics $3 \& 4$ present ranges for the left and right leg distribution between measures in group Band the means were around 50 for both the first and second measurements (Graphics 3\&4).

When we compared the differences between Graphic $1 \& 2$ and Graphic 3\&4, we could see a bigger change in the range of both leg BW\% in Graphics $1 \& 2$

\section{DISCUSSION}

CETE and core stabilization exercises are the most discussed and researched subjects in the literature. Yet, training through trunk training machines such as Freespine ${ }^{\mathrm{TM}}$ is less seen. This study has an importance since being the first and pilot study, and also examining the effects of it.

According to the results of the study, there was a significant difference in total TTM-Work and CETE-Work. Multifidus muscle, being one of the core muscle, and longissimus branch of erector spinae muscle, being one of the postural muscles, revealed less muscle activity in TTM intervention than CETE. Similar results can be seen in the literature that multidimensional, static and dynamic, aerobic, strength and flexibility exercises improve the balance ability and reduce falls in geriatric population through increasing postural control $(33,34)$. Besides that, Theraband ${ }^{\mathrm{TM}}$ exercises and ball training in lying/sitting position to stretch, strength and incre- 
ase the balance improves postural sway and functional reach in older individuals $(34,35)$. Multimodal approach, contralateral and ipsilateral patterns, instead of static surface, on the ball help to gain internalized dynamic balance system in geriatric population. Therefore, the use of air filled ball in conjunction with functional tasks was effective in increasing strength in antigravity trunk musculature, increasing postural awareness and maintaining good balance (34).

Although there was a significant difference between SEMG activities during total TTM and CETE interventions, no significant difference was found between measures for both of groups in the first and second BW\% measurements. The literature about the effect of functional training including BW\% points out that, a weight-shift training program improves balance control but not weight distribution in a group of chronic stroke subjects. Even one research has reached these results (36), another research has shown that symmetrical BW\% training may improve sit-to-stand performance and consequently, decrease the number of falls in the same population (37).

Although no significant differences were found on the weight distribution between the left and right legs in both groups, before and after the intervention program, there was a significant difference of the values of the ranges in TTM group for both legs, which was marked as bigger than CETE group. It is considered that, in comparison with CETE, TTM training appear to demand less muscle activity, thus less energy consuming and to produce better stance outcome at the same time. The strong side of our study was that it included objective outcome measurements such as surface EMG (38) and force plate weight bearing assessment and the same training protocol for both intervention groups. Additionally, this research is unique for using Freespine $^{\mathrm{TM}}$ and also, there is small number of studies about TTMs comparing with CETE and core stabilization exercises in the literature.

However, it is considered that having a small sample size and being a pilot study are the limitations of this study. The reason of the small sample size is that, we chose subjects with low to medium level of athletic experience and excluded systematic athletes.
We are planning more research in this field on other populations such as geriatrics. In addition to this, we think that including more participants for the further researches will reveal the effect of TTM on BW\%, clearly.

In conclusion, using TTM may be beneficial for $3 \mathrm{di}-$ mensional training of spine, core and back muscles with less time, effort and energy..

\section{REFERENCES}

1. Ridder E, van Oosterwijck JO, Vleeming A, Vanderstraeten GG, Danneels LA. Posterior muscle chain activity during various extension exercises: An observational study. BMC Musculoskel Dis. 2013;14(1):1-11.

2. Hibbs AE, Thompson KG, French D, Wrigley A, Spears I. Optimizing performance by improving core stability and core strength. Sports Med. 2008;38(12):995-1008.

3. Young $W$, Rath DA. Enhancing foot velocity in football kicking: The role of strength training. J Strength Cond Res. 2011;25:5616.

4. Durall CJ, Udermann BE, Johansen DR, Gibson B, Reineke DM, Reuteman $P$. The effects of preseason trunk muscle training on low-back pain occurrence in women collegiate gymnasts. J Strength Cond Res. 2009;23(2):86-92.

5. Imai A, Kaneoka K, Okubo Y, Shiina I, Tatsumuna M, Izumi S, et al. Trunk muscle activity during lumbar stabilization exercises on both a stable and unstable surface. J Orthop Sports Phys Ther. 2010;40(6):369-75.

6. Axler CT, McGill SM. Low back loads over a variety of abdominal exercises: Searching for the safest abdominal challenge. Med Sci Sports Exerc. 1997;29(6):804-11.

7. Butcher SJ, Craven BR, Chilibeck PD, Spink KS, Grona SL, Sprigings EJ. The effect of trunk stability training on vertical takeoff velocity. J Orthop Sports Phys Ther. 2007;37(5):223-31.

8. Leetun DT, Ireland ML, Willson JD, Ballantyne BT, Davis IM. Core stability measures as risk factors for lower extremity injury in athletes. Med Sci Sports Exerc. 2004;36(6):926-34.

9. O'Sullivan PB, Phyty GD, Twomey LT, Allison GT. Evaluation of specific stabilizing exercise in the treatment of chronic low back pain with radiologic diagnosis of spondylolysis or spondylolisthesis. Spine. 1997;22(24):2959-67.

10. Rasmussen-Barr E, Ang B, Arvidsson I, Nilsson-Wikmar L. Graded exercise for recurrent low-back pain: A randomized, controlled trial with 6-, 12-, and 36-month follow-ups. Spine. 2009;34(3):221-8.

11. Jung J, Yu J, Kang $H$. Differences in trunk muscle activities and ratios between unstable supine and prone bridging exercises in individuals with low back pain. J Phys Ther Sci. 2012:24:889-92.

12. Kim JW, Han JY, Kang MH, Ha SM, Oh JS. Comparison of posterior oblique sling activity during hip extension in the prone position on the floor and on a round foam roll. J Phys Ther Sci. 2013;25:977-9.

13. Peterson C, Nittinger N. Connecting the core: Exercises to enhance stability. J Med Sci Tennis. 2013;18(1):13-20.

14. Ferri A, Scaglioni G, Pousson M, Capodaglio P, van Hoecke J, Narici MV. Strength and power changes of the human plantar flexors and knee extensors in response to resistance training in old age. Acta Physiol Scand. 2003;177(1):69-78.

15. Hakkinen K, Hakkinen A. Neuromuscular adaptations during intensive strength training in middle-aged and elderly males and females. Electromyogr Clin Neurophysiol. 1995; 35(3):13747. 
16. Hakkinen K, Newton RU, Gordon SE, McCormick M, Volek JS, Nindl BC, et al. Changes in muscle morphology, electromyographic activity, and force production characteristics during progressive strength training in young and older men. J Gerontol A Biol Sci Med Sci. 1998;53(6):B415-23.

17. Kryger Al, Andersen JL. Resistance training in the oldest old: Consequences for muscle strength, fiber types, fiber size, and MHC isoforms. Scand J Med Sci Sports. 2007;17(4):422-30.

18. Blazevich AJ, Cannavan D, Coleman DR, Horne S. Influence of concentric and eccentric resistance training on architectural adaptation in human quadriceps muscles. J Appl Physiol. 2007;103(5):1565-75.

19. Manini TM, Clark BC, Tracy BL, Burke J, Ploutz-Snyder LL. Resistance and functional training reduces knee extensor position fluctuations in functionally limited older adults. Eur J Appl Physiol. 2005;95(5-6):436-46.

20. Tracy BL, Byrnes WC, Enoka RM. Strength training reduces force fluctuations during an isometric contractions of the quadriceps femoris muscles in old adults. J Appl Physiol. 2004;96(4):153040.

21. Hess JA, Woollacott M. Effect of high-intensity strength-training on functional measures of balance ability in balance-impaired older adults. JMPT. 2005;28(8):582-90.

22. Ryushi T, Kumagai K, Hayase H, Abe T, Shibuya K, Ono A. Effect of resistive knee extension training on postural control measures in middle aged and elderly persons. J Physiol Anthropol Appl Human Sci. 2000;19(3):143-9.

23. Cunha ACV, Burke TN, França FJR, Marques AP. Effect of global posture reeducation and of static stretching on pain, range of motion, and quality of life in women with chronic neck pain: a randomized clinical trial. Clinics. 2008;63(6):763-70.

24. López-Miñarro P, Muyor J, Belmonte F, Alacid F. Acute effects of hamstring stretching on sagittal spinal curvatures and pelvic tilt. J Hum Kinet. 2012;31:69-78.

25. Carter JM, Beam WC, McMahan SG, Barr ML, Brown LE. The effects of stability ball training on spinal stability in sedentary individuals. J Strength Cond Res. 2006;20(2):429-35.

26. Cosio-Lima LM, Reynolds KL, Winter C, Paolone V, Jones MT. Effects of physioball and conventional floor exercises on early phase adaptations in back and abdominal core stability and balance in women. J Strength Cond Res. 2003;17(4):721-5.

27. Heitkamp HC, Horstmann T, Mayer F, Weller J, Dickhuth HH. Gain in strength and muscular balance after balance training. Int J Sports Med. 2001;22:285-90.

28. Stanton R, Reaburn PR, Humphries B. The effect of short-term Swiss ball training on core stability and running economy. J Strength Cond Res. 2004;18(3):522-8.

29. Tse MA, McManus AM, Masters RSW. Development and validation of a core endurance intervention program: Implications for performance in college-age rowers. J Strength Cond Res. 2005;19(3):547-52.

30. Kaji A, Sasagawa S, Kubo T, Kanehisa H. Transient effect of core stability exercises on postural sway during quiet standing. J Strength Cond Res. 2010;24(2):382-8.

31. Freespine [homepage on the internet]. [cited 2015 July 28]. Available from: http://www.freespine.com/en/.

32. The Surface ElectroMyoGraphy for the Non-Invasive Assessment of Muscles Project [homepage on the internet]. Enschede: The SENIAM Project; [cited 2015 Aug 1]. Available from: http:// www.seniam.org/

33. Shumway-Cook A, Woollacott MH. Aging and postural control. In: Shumway Cook, Woollacott WH, editors. Motor control: theory and practical application. Baltimore:LWW, 1997; p. 222-47.

34. Jahagirdar SS, Kenkre IR. Training elderly for mobility and strength using emgbiofeedback and swiss ball/ peanut ball exercises. IJOT. 2010;42(1):17-25.

35. Roger ME, Fernandez JE, Bohlken RM. Training to reduce postural sway and increase functional reach in the elderly. J Occup Rehabil. 2001;11(4):291-8.

36. Tsaklis PV, Grooten WJA, Franzén E. Effects of weight-shift training on balance control and weight distribution in chronic stroke: a pilot study. Top Stroke Rehabil. 2012;19(1):23-31.

37. Cheng PT, Wu SH, Liaw MY, Wong AMK, Tang FT. Symmetrical body-weight distribution training in stroke patients and its effect on fall prevention. Arch Phys Med Rehabil. 2001;82(12):16504.

38. İnanoğlu D, Baltacı G. Nörolojik defisiti olmayan bel ağrılı hastalarda farklı bantlama tekniklerinin yaşam kalitesi ve ağrı üzerine etkisi. J Exerc Ther Rehabil. 2014;1(1):26-34. 